
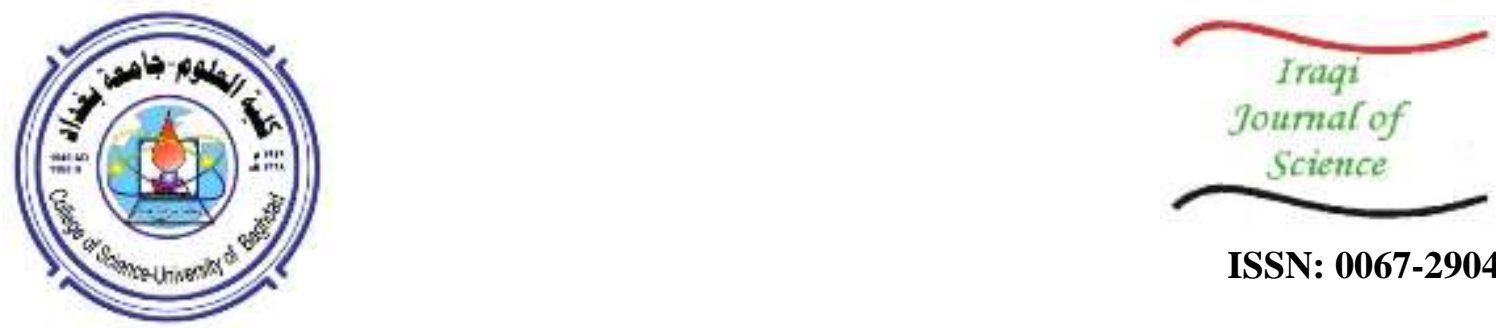

ISSN: 0067-2904

\title{
Analysis of Morphological Features of Sargalu Region in Sulaymaniyah Governorate, North of Iraq, by using Geographic Information System
}

\begin{abstract}
Ali Abdul-Jaleel Hussain*, Muaid Jassim Rasheed
Department of Geology, College of Science, Baghdad University, Baghdad, Iraq

Received: 23/3/2020

Accepted: 21/7/2020

Abstract

It is an ideal area of research to examine related indicators to anticipate relative tectonic activities, where there is a broad range of geological formations with elements of different sedimentary rocks. This study includes assessing and evaluating the relative tectonic activities within the Sargalu area by using a morphometric approach, which involved the use of different indices that can explain and help understanding the geometry, development level, lithology, and structural disturbance on a sub-basinal level. The research was accomplished by using ArcGIS 10.5 hydrology tools to design the drainage system of each studied stream. The Advanced Spaceborne Thermal Emission Radiometer (ASTER) satellite imagery data and the Digital Elevation Model (DEM 90m) were used. Moreover, Global Mapper and Statistical Package for the Social Sciences (SPSS) were applied. DEM datasets of ASTER were used for watershed delineation. Also, 14 sub-basins were delineated in the Sargalu area. Morphometric indices used include Shape Related Indices, such as Rc, Bs, Rf, Ls, Re, T, and Af. Basin asymmetry factor (Af) and several geomorphic indices were also utilized. Based on the shape related indices ( Rc, Rf, Re, Ls, and Cc), the results were found to be similar and, for most subbasins, had an elongated nature. The elongated basins are connected with tectonically active areas, while the circulated basins are connected with the tectonically undisturbed environment.
\end{abstract}

Keywords: Generate drainage basin, GIS techniques, Morphometric indices, Sargalu region Geomorphic and satellite Aster Imagery analysis.

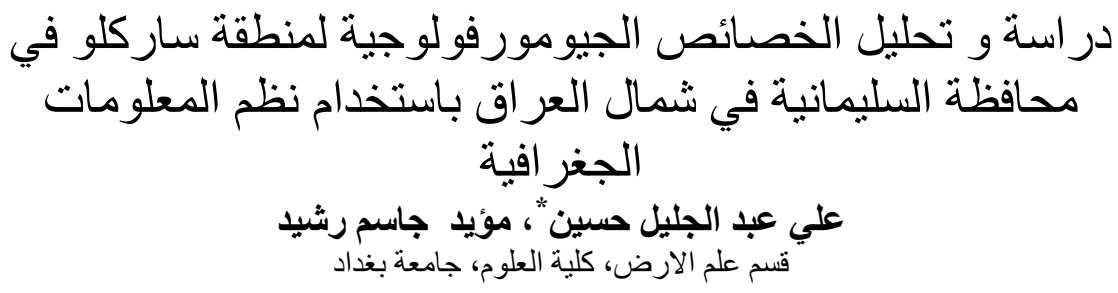

الخلاصة

إنها منطقة مثالية لفحص المؤشر لتتبؤ النشاط التكتوني النسبي ، بالإضافة إلى اعتباره منطقة مميزة

للغاية. حيث توجد مجموعة كبيرة من التراكيب الجيولوجية. عناصر التكوبنات من الصخور الرسوبية المختلفة.

شملت دراسته تقييم وتقييم النشاط التكتوني النسبي داخل منطقة ساركلو باستخدام نهج مورفومتري ، والذي مني

تضمن استخدام مؤشرات مختلفة يمكن أن تشرح وتساعد في فهم الهندسة ومسنوى النطوير والليثولوجيا

والاضطراب التركيبي على المستوى الأساسي. تم الانتهاء من البحث باستخدام تقنيات (ArcGIS 10.5) تم

استخدام أدوات الهيدرولوجيا لتصميم نظام الصرف لكل مجرى مدروس. تم استخدام بيانات صور أستر

الفضائية ، نموذج الارتفاع الرقمي (DEM 90m). علاوة على ذلك ، تم استخدام مخطط عالمي و (الحزمة 


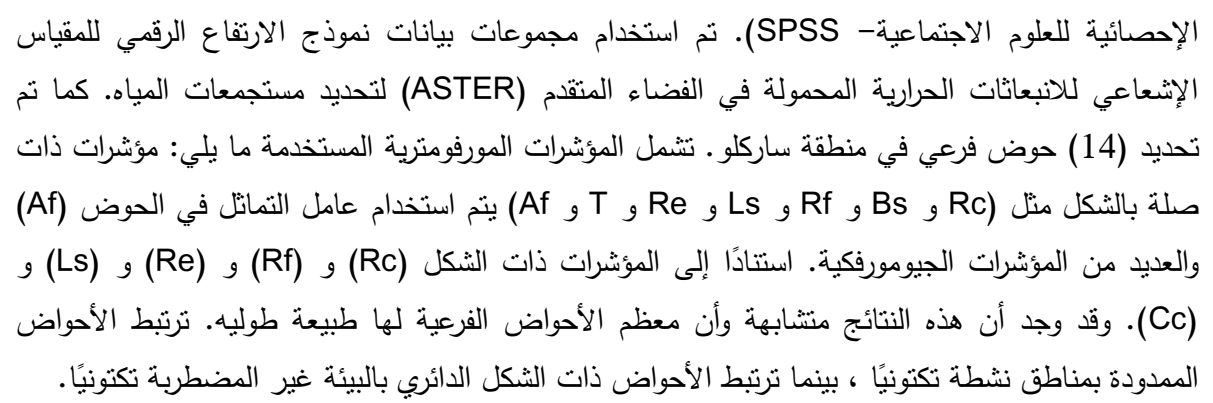

\section{Introduction}

General geomorphometry is the calculation and investigation of the characteristics of landform which can be applied to any sort of rough continuous surfaces [1]. The current worldwide accessibility of DEM drives the designing of novel procedures to effectively apply the principles of geomorphometry in the territories for which the geomorphic mapping is immature and deficient $[2,3]$. The explanation of the diversity of geomorphology can be provided through several morphogenesis affecting factors, e.g. tectonic and climate change history, that affect the region contrarily relying on its lithology [5]. Such factors result in landform diversity in a place of natural things separating the surface of the earth. as Also, such factors impact the definition of the conditions of boundaries for the methods operative in fields of pedology, ecology, hydrology, geomorphology, and several others [6, 7]. The geomorphological diversification was demonstrated to be an essential explaining feature to provide the variations in the functioning of the forest ecosystem and patterns of spatial biodiversity, which were detected at local scale and regional scales $[9,10,11]$. Landform quantitative measurements are achieved on the basis of geomorphic indices calculation. However, a single index is not adequate to measure an area's degree of tectonic activity. Quantification is usually subsequent to the procurement of essential information from satellite data, aerial photographs, and topographic maps [12]. An assimilated multidisciplinary method utilizing structural, geomorphological, and neotectonic data is extremely helpful in the active tectonics evaluation [13]. The morphotectonic characteristics are an exceptional indicator to explore the comparative tectonic activities $[14,15,16]$. Thus, we investigated 6 geomorphic indices, namely the valley floor width-valley height ratio (Vf), hypsometric integral (Hi) with a convex-up hypsometric curve, topographic asymmetry (TA), drainage basin asymmetry (AF), steam gradient index (SL), circulatory ratio (KA), basin shape of drainage (Eb), and mountain front sinuosity (Smf) to deduce the dynamic tectonic marks. The computed geomorphic indices were further associated to illustrate the comparative active tectonics.

\section{Location and Description of the Study Area}

The study area is located in the northeastern part of Iraq. According to the tectonic map [17], it is placed within the High Folded Zone (HFZ) and the Imbricated Zone (IZ) [18], which is a part of the Unstable Shelf. It covers about $2980.788959 \mathrm{~km}^{2}$, lying between the longitude of $\left(44^{\circ} 58^{\prime}-45^{\circ} 21^{\prime} \mathrm{E}\right)$ and the latitude of $\left(35^{\circ} 48^{\prime}-36^{\circ} 00^{\prime} \mathrm{N}\right)$, as illustrated in Figure-1. The folds in this area include weelana, bana bareek, yakhyan, kalo, khalikan, dolmazala, surdash, sulaimaniyah, pere magrun, and dokan. 


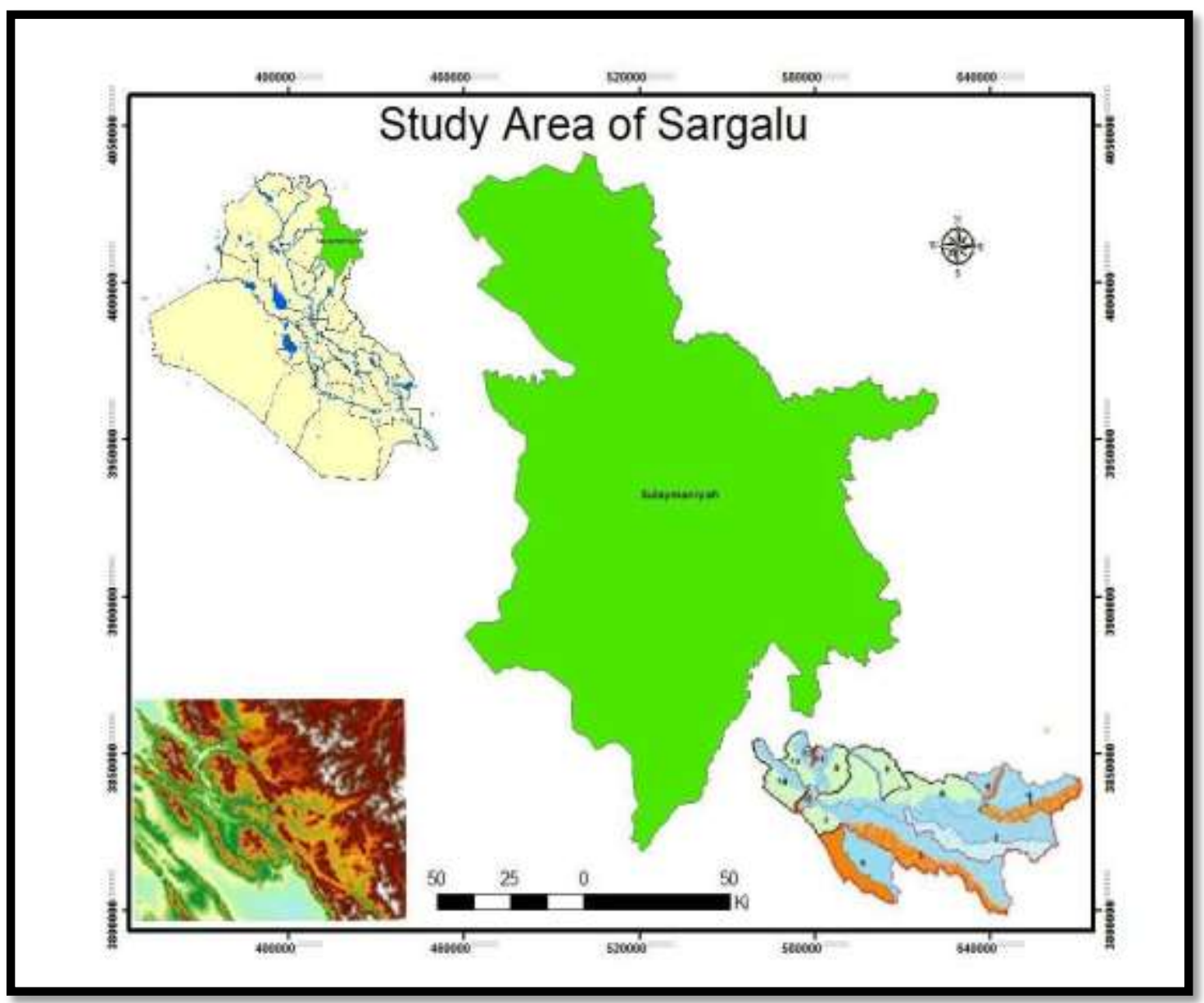

Figure 1-Location map of the Sargalu Area (SA).

The area of this study is located along the Iraqi - Iranian border, which is featured by the High Folded Zone, Imbricate Zone, Zagros Suture Zone, and Shalair Zone. Geomorphologically, the study area has a mountainous terrain with a peak of 3140 meters a.s.l. in the northeastern part and a minimum elevation of 459 meters a.s.l.. This implies that the area increases in height to the northeast. Geologically, it is a highly complicated study area. The age of the exposed formations is from Jurassic to Holocene with different types of quaternary sediments. The anticline folds include the oldest exposed rocks in Iraq, along with a major fault creep that runs from the northeast to the northwest, which forms the tectonic connection between the superposition regions and the elevated regions. The folds that are located in the northeastern part have the direction of the northeast-southwest, and they are parallel to the thrust belt, Zagross, whereas the northwestern wings extend to the greater Zab River where their directions change toward east-west. The Sargalu Area crosses the areas of weelana, bana bareek, yakhyan, Kalo, khalikan, dolmazala, surdash, Sulaymaniyah, pere magrun, and dokan folds.

\section{Structural Geology}

According to Figure-2, 3 the studied region is placed inside the High Folded, Imbricate, Zagros Suture Zone and Shalair zone, all of which belonging to the Unstable Shelf of the Arabian Plate [19, 20]. Several anticlines and synclines are developed, all being in the NW - SE trend. However, in the extreme northwestern part of the area, their trend changes toward $\mathrm{E}-\mathrm{W}$. . The main anticlines, from the north to the south, within the studied area are Pera Magrun Anticline, Sulaimanya Anticline, Klo Anticline, Bana-Bareek Anticline, Weelana Anticline, and Khalikan Anticline. The names of the anticlines are based on [19], while the names of the thrust sheets are based on [20]. 


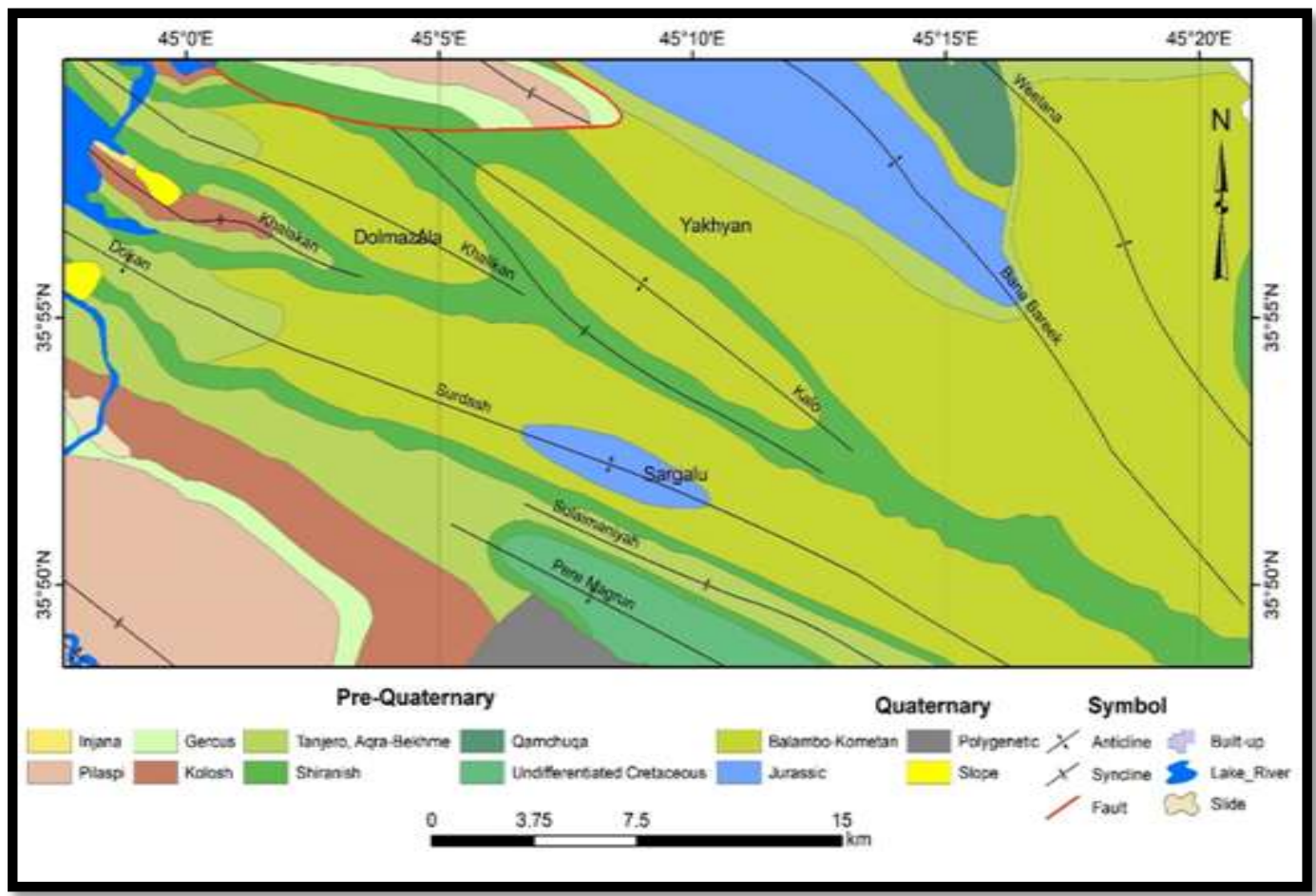

Figure 2-Geological map of the study area. The Sargalu is marked with the blue ellipse shape [21].

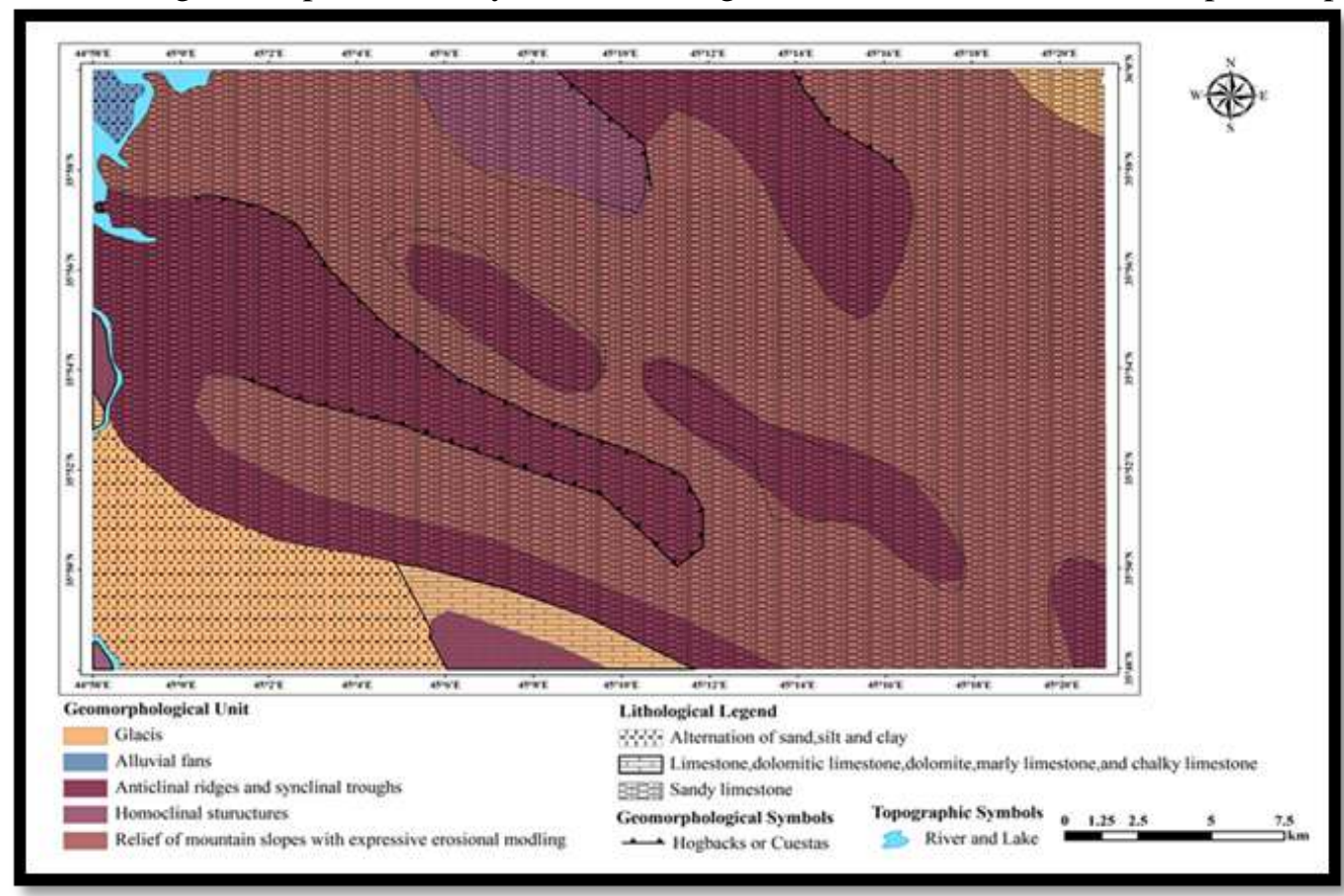

Figure 3-Geomorphological Map of the Study area [22].

\section{Methodology}

Morphometric features such as aerial, linear, and relief aspects, along with a number of geomorphic parameters, were collected using satellite digital images and supporting data. This approach was adopted due to the fact that the manual extraction of networks and assigning the stream order from the published topography map of Iraq and geo-referenced satellite data for a large area is a time consuming exercise. Geographic information systems (GIS) and remote sensing techniques are used as suitable tools to produce spatial variation in morphometric variables. Remote sensing data obtained from sensors such as ASTER Global Digital Elevation Model (GDEM), with a Resolution of $90 \mathrm{~m}$, in addition to other supporting data, such as topographic (scale 1:2,500,000) and geologic maps 
were also used to determine the drainage networks and the morphometric parameters of the Sargalu area (SA) and its sub-basins. ArcGIS 10.5 software was used to extract drainage networks and generate drainage basin characteristics. More specifically, the extracted SB and its sub-basins and stream networks are projected to the regional projection (WGS-1984, UTM Zone $38 \mathrm{~N}$ ) and the hydrology of the ArcGIS software toolbox. The automated method for delineating drainage was performed using GIS. Different morphometric parameters were determined, as shown in Table-1.

Table 1-The relief linear and morphometric areal parameters used for Sargalu Area Watershed.

\begin{tabular}{|c|c|c|}
\hline S.no. & Parameter & Formula \\
\hline 1 & Stream length $(\mathrm{Lu})$ & Length of the length stream \\
\hline 2 & Stream order $(\mathrm{U})$ & Hierachial rank \\
\hline 3 & Stream length ratio (RL) & $\mathrm{RL}=\mathrm{Lu} / \mathrm{Lu}-1$ \\
\hline 4 & Mean stream length (Msl) & $\mathrm{MSL}=\mathrm{Lu} / \mathrm{Nu}$ \\
\hline 5 & Mean bifurcation ratio $(\mathrm{Rbm})$ & $\begin{array}{c}\mathrm{Rbm}=\text { Average of bifurcation } \\
\text { ratios of all orders }\end{array}$ \\
\hline 6 & Bifurcation ratio $(\mathrm{Rb})$ & $\mathrm{Rb}=\mathrm{Rb}=\mathrm{Nu} / \mathrm{Nu}+1$ \\
\hline 7 & Stream frequency $(F s)$ & $\mathrm{Fs}=\mathrm{Nu} / \mathrm{Ba}$ \\
\hline 8 & Drainage density $(\mathrm{Dd})$ & $\mathrm{Dd}=\mathrm{Lu} / \mathrm{Ba}$ \\
\hline 9 & Elongation ratio $(R e)$ & $\mathrm{Re}=2 \sqrt{((\mathrm{Ba} / \pi)) / \mathrm{Lb}}$ \\
\hline 10 & Drainage texture $(\mathrm{T})$ & $\mathrm{T}=\mathrm{Dd} \times \mathrm{Fs}$ \\
\hline 11 & Circularity ratio $(\underline{R c})$ & $\mathrm{Rc}=4 \times \pi \times \mathrm{Ba} / \mathrm{P}^{2}$ \\
\hline 12 & Form factor $(R f)$ & $\mathrm{Rf}=\mathrm{Ba} / \mathrm{Lb}^{2}$ \\
\hline 13 & Compactness coefficient $(C c)$ & $\mathrm{Cc}=0.2841 \times\left(\mathrm{P} / \mathrm{Ba}^{0.5}\right)$ \\
\hline 14 & Basin relief $(R)$ & $\mathrm{R}=\mathrm{H}_{\max }-\mathrm{H}_{\min }$ \\
\hline 15 & Relief ratio $(R h)$ & $\mathrm{Rh}=\mathrm{H} / \mathrm{Lb}$ \\
\hline 16 & Constant channel maintenance $(C)$ & $\mathrm{C}=1 / \mathrm{Dd}$ \\
\hline 17 & Drainage intensity $(D i)$ & $\mathrm{Di}=\mathrm{Fs} / \mathrm{Dd}$ \\
\hline 18 & Lemniscate shape ratio (Ls) & $\mathrm{Ls}=(\mathrm{Lb}) 2 * \pi / 4 \mathrm{Ba}$ \\
\hline
\end{tabular}

\section{Results}

\section{Extraction of the Watershed of Sargalu Area}

ASTER DEM imagery data with a spatial resolution of $90 \mathrm{~m}$ for Sargalu Area were automatically extracted. The extraordinary geological processing techniques in ArcGIS 10.5 aided in extracting the basin area. The DEM and the pour point are the two input parameters required for the extraction. A pour point is a user-supplied point to the cells of the highest flow accumulation [22]. The method of the automatic extraction of the basin/watershed is displayed in Figure-4. These results of the process will begin to a watershed boundary polygon from the flow direction raster data. Using ArcGIS 10.5 the drainage network in Sargalu Area was obtained from an accumulation of geoprocessing tools. This process is considered as central to provide a stream/drainage network grid with stream order [23]. In the Sargalu Area, the highest steam order was distinguished as being the sixth order. Standard mathematical methods were followed using the parameters provided in Table-1. The various parameters interpreted, such as stream code, stream length, number, basin relief, stream length ratio, bifurcation ratio, basin length, basin area, elongation ratio, relief ratio, drainage density, etc.. To assist the drainage morphometric basin, the aspect and slope map of the study area was derived from the ASTER DEM using the aspect and slope tool in ArcGIS-10.5 spatial analyst module.

\section{Morphometric analysis and geomorphic indices}

Active tectonics Morphometric Analysis of basin

Morphotectonic quantitative parameters are used to study the active tectonics and morphological relationships [22- 27]. The drainage network of the watershed and stream ordering was examined based on several formulae used in this study, as shown in Table-2. The morphometric parameters were classified into three groups, namely the basic parameters, derived parameters, and shape parameters. The basic parameters contain area $(\mathrm{Ba})$, perimeter $(\mathrm{P})$, basin length $(\mathrm{Lb})$, stream order $(\mathrm{U})$, and stream length $(\mathrm{Lu})$. The derived parameters include stream length ratio (Lur), bifurcation ratio $(\mathrm{Rb})$, and Drainage density $(\mathrm{Dd})$. The shape parameters include elongation ratio $(\mathrm{Re})$, circulatory ratio $(\mathrm{Rc})$, and form factor (Rf). 


\section{Basic Parameters}

The values in Table- 2 represent the morphometric analysis of Sargalu watershed. The elementary parameters include the watershed area, stream length, perimeter, stream order, and basin length.

Table 2-Characteristics of the drainage basins

\begin{tabular}{|c|c|c|c|c|c|c|}
\hline Sub-basin & Order & $\begin{array}{c}\text { Stream } \\
\text { number }\end{array}$ & $\begin{array}{c}\text { Stream } \\
\text { length }(\mathrm{km})\end{array}$ & $\begin{array}{c}\text { Basin area } \\
(\mathrm{km} 2)\end{array}$ & $\begin{array}{c}\text { Perimeter } \\
(\mathrm{km})\end{array}$ & $\begin{array}{c}\text { Basin } \\
\text { length }(\mathrm{km})\end{array}$ \\
\hline 1 & 4 & 138 & 258.064 & 323.909 & 111.307 & 32.4 \\
\hline 2 & 4 & 221 & 425.996 & 505.589 & 153.067 & 48.93 \\
\hline 3 & 4 & 223 & 409.535 & 550.659 & 181.713 & 58.66 \\
\hline 4 & 4 & 133 & 256.037 & 328.529 & 95.961 & 32.51 \\
\hline 5 & 4 & 31 & 51.652 & 63.516 & 44.280 & 12.81 \\
\hline 6 & 5 & 197 & 387.147 & 509.635 & 191.236 & 52.62 \\
\hline 7 & 5 & 53 & 92.981 & 111.902 & 55.528 & 18.39 \\
\hline 8 & 4 & 55 & 107.838 & 129.288 & 69.189 & 21.77 \\
\hline 9 & 3 & 41 & 82.711 & 112.194 & 52.380 & 16.28 \\
\hline 10 & 6 & 16 & 20.916 & 30.574 & 29.886 & 9.16 \\
\hline 11 & 3 & 16 & 19.952 & 27.555 & 24.223 & 8.44 \\
\hline 12 & 6 & 40 & 75.032 & 111.107 & 68.406 & 19.86 \\
\hline 13 & 3 & 9 & 10.251 & 13.880 & 15.779 & 4.91 \\
\hline 14 & 4 & 54 & 109.551 & 162.445 & 77.047 & 27.11 \\
\hline
\end{tabular}

\section{Perimeter and Area in Sargalu area}

The elementary morphometric parameters of the delineated layer of the mini-watershed were examined, including area $(A)$, length $(\mathrm{L})$, perimeter $(\mathrm{P})$, and number of streams $(\mathrm{N})$. Basin length $(\mathrm{Lb})$ was measured from the stream length, while the bifurcation ratio $(\mathrm{Rb})$ was measured from the number of streams. Other linear and morphometric parameters were measured using the equations shown in Table-3.

Table 3-Characterisitcs of the Sargalu Area

\begin{tabular}{|c|c|}
\hline Coverage area & 2980.78 \\
\hline Length of the basin & 99.81 \\
\hline Width of the basin & 41.78 \\
\hline Length of the stream & 114.90 \\
\hline Highest point in basin & 3140 \\
\hline Lowest point in basin & 459 \\
\hline Perimeter of the basin & 1170 \\
\hline Channel Sinuosity: Before outlet/ After outlet & Regular \\
\hline \multicolumn{2}{|l|}{} \\
\hline \multicolumn{2}{|l}{} \\
\hline \multicolumn{2}{|l}{} \\
\hline
\end{tabular}

\section{Shape Parameters of Sargalu area}

Table-4 lists the results of Form factor (Rf), Basin Shape index (Bs), Circulatory Ratio (Rc), Elongation Ratio (Re), Lemniscate shape ratio (Ls) (Ls) and Compactness Coefficient (Cc). Their results were found to be similar and indicated that most of the sub-basins had an elongated nature, as illustrated in Figure-5. In the area, the values of elongation ratio ranged from 0.05 (sub-basin 3) to 0.11 (sub-basin 13) symbolizes which the very elongated to the near-circular form of the basins severally. The more elongated basins are located in the north-west while those less elongated are present in the north-eastern part of the study region. 


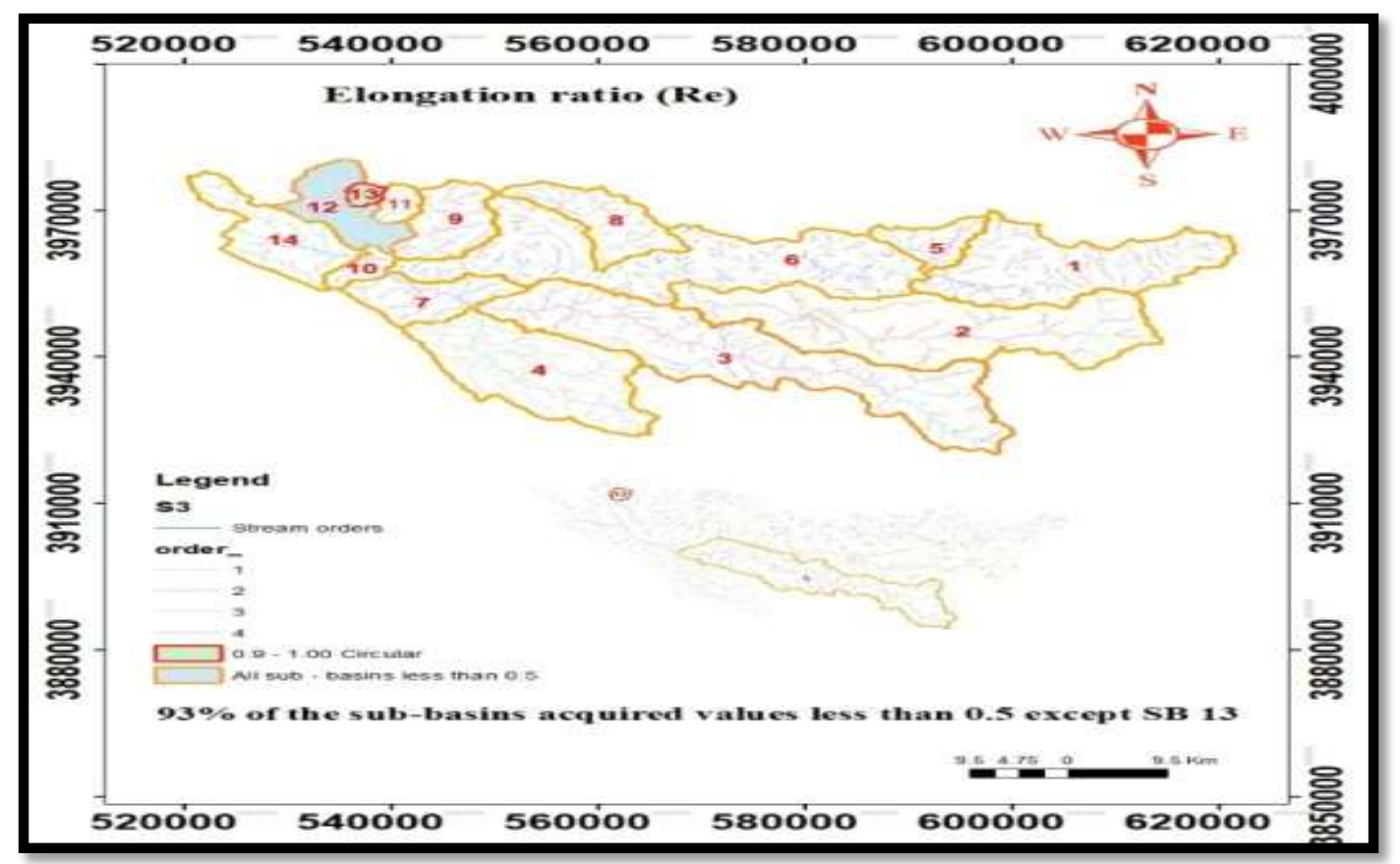

Figure 4-Distribution of (Re) throughout the study area

Table 4-Detailed results of the shape and symmetry related indices.

\begin{tabular}{|l|l|l|l|l|l|}
\hline Sub - basin & $(\mathbf{R f})$ & $(\mathbf{R e})$ & $(\mathbf{R c})$ & $(\mathbf{L s})$ & $(\mathbf{C c})$ \\
\hline $\mathbf{1}$ & & & & & 0.04 \\
$\mathbf{2}$ & 0.30 & 0.08 & 0.32 & 3.24 & 0.04 \\
$\mathbf{3}$ & 0.21 & 0.06 & 0.27 & 4.73 & 0.04 \\
$\mathbf{4}$ & 0.15 & 0.05 & 0.21 & 6.24 & 0.04 \\
$\mathbf{5}$ & 0.31 & 0.08 & 0.45 & 3.21 & 0.09 \\
$\mathbf{6}$ & 0.38 & 0.09 & 0.40 & 2.58 & 0.05 \\
$\mathbf{7}$ & 0.18 & 0.06 & 0.17 & 5.43 & 0.07 \\
$\mathbf{8}$ & 0.32 & 0.08 & 0.46 & 3.02 & 0.07 \\
$\mathbf{9}$ & 0.27 & 0.07 & 0.34 & 3.66 & 0.06 \\
$\mathbf{1 0}$ & 0.42 & 0.09 & 0.52 & 2.36 & 0.13 \\
$\mathbf{1 1}$ & 0.35 & 0.08 & 0.44 & 2.74 & 0.12 \\
$\mathbf{1 2}$ & 0.37 & 0.09 & 0.58 & 2.58 & 0.08 \\
$\mathbf{1 3}$ & 0.28 & 0.07 & 0.30 & 3.54 & 0.16 \\
$\mathbf{1 4}$ & 0.53 & 0.11 & 0.72 & 1.73 & 0.06 \\
& 0.22 & 0.07 & 0.34 & 4.52 & \\
\hline
\end{tabular}

\section{Geomorphic parameters}

A mix of two types of parameters, namely the mountain front sinuosity and valley floor width to valley height ratio, was utilized to provide semi-quantitative data of related level of tectonic activity of mountain fronts $[28,29]$. Two subjects applying certain signs provide an assignation to various tectonic activity groups.

\section{Mountain front sinuosity $\left(S_{m f}\right)$}

The length the complete the rate of the hill front as included along with the prominent fracture in slope along the foot of a mountain and the straight-line length of the mountain Front, [30]. It is calculated by the following equation:

$\mathrm{Smf}=\mathrm{Lmf} / \mathrm{LS}$

The index presents a scale between the tendency of streams and slope methods to provide an irregular (sinuous) mountain front and vertical active tectonics that tend to give a prominent straight front [29]. 
Table 5-Tectonic activity and the relation between results

\begin{tabular}{|c|c|c|}
\hline Class & Tectonic activity & Value \\
\hline 1 & Extremely active & $<1.02$ \\
\hline 2 & Moderately active & $>1.02-1.04$ \\
\hline 3 & Active & $>1.04$ \\
\hline
\end{tabular}

The Smf index is essential since it can be simply estimated by using the satellite, aerial photographs, or other high altitude imagery or topographic maps. Can mountain fronts be calculated manually from the topographic maps of high-resolution and satellite images? To measure mountain front sinuosity in the Sargalu region, DEMs produced by stereo image bands 3N and 3B of ASTER were used. 3-D surfaces were produced by using Global Mapper version 11. Smf Uses of approach 1.0 on the common tectonically active fronts, whereas Smf develops if the rate of uplift is decreased and erosional processes start to form a front that displays further irregular with time. Rates lower than 1.4 symbolize tectonically active fronts $[21,31]$. while more chief Smf uses $(3 \mathrm{~N})$ are usually correlated with inactive fronts, Smf rates lower than 1.4 stewarded sub-basins $(1,3,5,6,9$ and 11). The region of Sargalu was divided into 14 sub-basins. Any protection in all of these sub-basins was traced and included, depending on the area of the basin. Hill front can be delimited as one main front separated into segments of many fronts of the same length or fronts connected with different lengths [31, 32, 33]. In this study, the latter approach was adopted because it has been more commonly used in research. Also, with this process, one can achieve better conclusions about the tectonics of the region. As for the sub-basins within the study area, the degree values were found to be ranging from 1.15 (sub-basin 3) to 2.29 (sub-basin 8).

\section{The Valley floor width to valley height ratio $(V f)$}

$\mathrm{V}_{\mathrm{f}}$ is another index of valley floor width to valley height rate, which is used evaluate the city the tectonic activity on the base of, [29]. The sign promotes the differentiation between the V-shaped valleys down cutting in response to active uplift, wherever the stream is dictated through the impact of a base level sin at some spot downstream that mention an almost high valleys with especially tectonic activity, and the U-shaped broad-floored lateral erosion into the near hill slopes in answer to related base-level balance or tectonic quiescence that signifies a relatively low tectonic activity. Accordingly, this tool achieves one vertical and one horizontal dimensions at a given point along the stream in the erosional system. The ratio of valley floor width to valley height is defined as: $\boldsymbol{V}_{f}=\mathbf{2} \boldsymbol{V}_{f w} /\left(\left(\boldsymbol{E}_{l d} \boldsymbol{E}_{s c}\right)+\right.$ $\left.\left(\boldsymbol{E}_{r d}-\boldsymbol{E}_{s c}\right)\right)$. The elevation and floor width values were obtained from the DEM of the knowledge space by saving the main stream for each sub-basin to a digital format, with three engineering pieces and three profiles that are drawn at the meeting points of segment, (upper, middle, and downstream), as demonstrated in Figure-5. According to an earlier report [34], through this parameter, the geometry of the transverse river profile can be described quantitatively and its possible tectonic influence on the river cross-section shape can be assessed. 


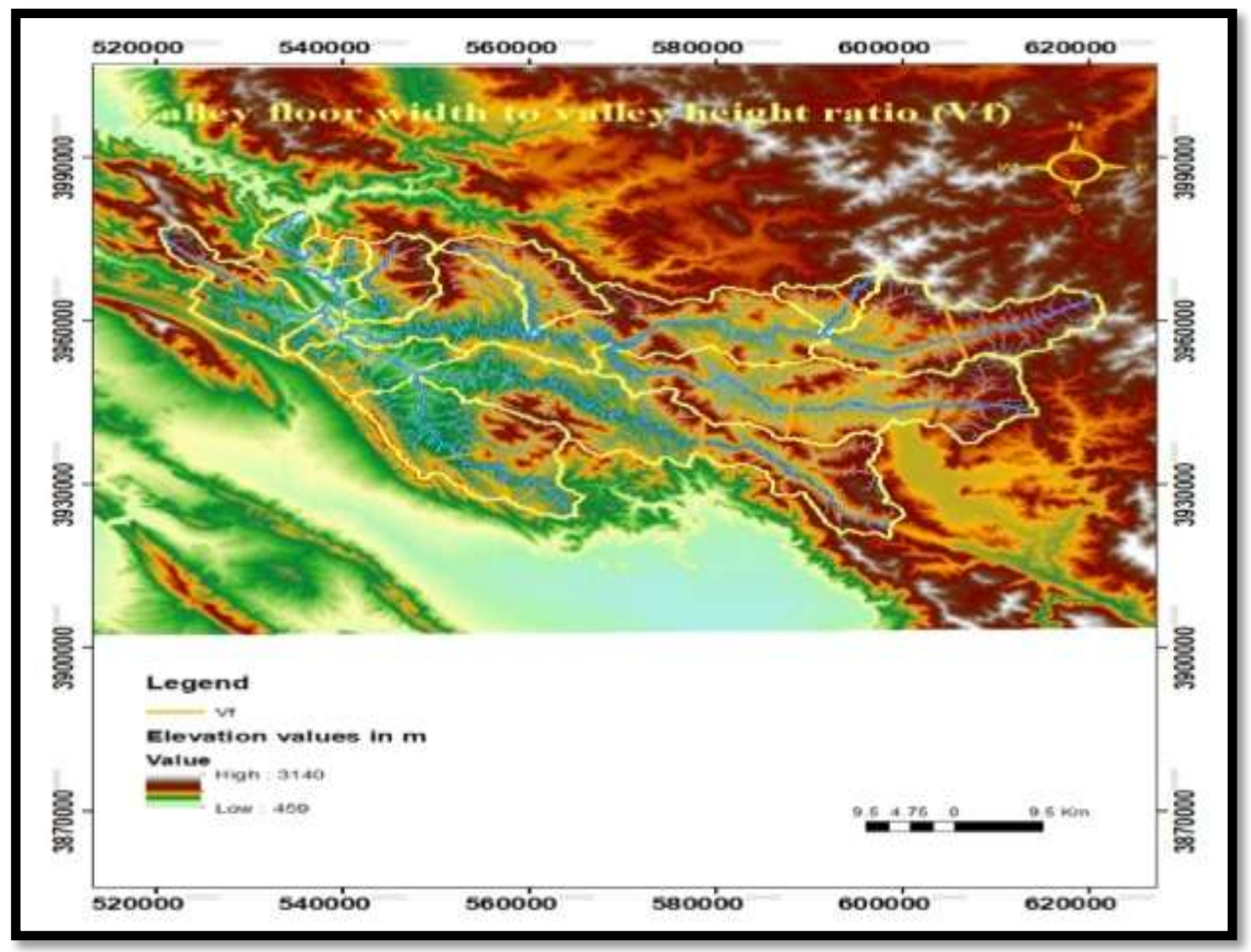

Figure 5-Profiling Locations for the calculation ( $V f)$.

As related to the sub-basins within the study area, the ratio values were found to be ranging from 0.09 (sub-basin 6) to 2.07 (sub-basin 11), as listed in Table-6. The lowest values fall within the subbasin that covers the upper part of the main river (ZSZ). It was also shown that the values tend to increase for the sub-basin that covers the lower part of the main river basin (HFZ).

Table 6-Relationship between results and Shape of the Valley

\begin{tabular}{|c|c|c|}
\hline Class & Shape of the Valley & Values \\
\hline $\mathbf{1}$ & indicates less eroded basin and V-shapedValleys & $0.05-0.12$ \\
\hline $\mathbf{2}$ & indicates eroded basin & $0.12-0.24$ \\
\hline $\mathbf{3}$ & indicates highly eroded basin and U-shaped Valleys & $0.24-0.4$ \\
\hline
\end{tabular}

\section{Basin shape index (Bs)}

The horizontal projection of a basin form may be explained by the basin shape index or the elongation ratio, Bs [27]. Bs was calculated by using the DEM and classified into three classes: Class 1 ( $\mathrm{Bs} \geq 4)$, Class $2(3 \leq \mathrm{Bs} \leq 4)$, and Class 3 (Bs $\leq 3)$ [28]. Bs ranges from 0.55 (sub-basin 1) to 2.86 (subbasin 11). Most of the maximum values of the examined sub-basins belong to classes 1 and 2, which are elongated with higher (Bs) values as compared to class 3 which reflects nearly circular shapes, as shown in Figure-6. High Bs values are associated with elongated basins, which are commonly associated with almost higher tectonic activity. Low Bs values reflect more circular-shaped basin, normally associated with low tectonic activity. Quickly uplifted mountain fronts generally provide elongated, steep basins; when tectonic activity is diminished or desists, the widening of the basins occurs from the mountain front [35].

Table 7-Values of different geomorphic indices in Sargalu region

\begin{tabular}{|c|c|c|c|}
\hline Sub-basin No. & $\mathbf{B}_{\mathbf{S}}$ & $\mathbf{S}_{\boldsymbol{m} \boldsymbol{f}}$ & $\mathbf{V}_{\mathbf{f}}$ \\
\hline $\mathbf{1}$ & 0.55 & 1.30 & 0.45 \\
\hline $\mathbf{2}$ & 1.36 & 1.60 & 0.32 \\
\hline $\mathbf{3}$ & 1.86 & 1.15 & 0.48 \\
\hline $\mathbf{4}$ & 1.60 & 1.48 & 0.18 \\
\hline $\mathbf{5}$ & 2.09 & 1.30 & 0.56 \\
\hline $\mathbf{6}$ & 1.55 & 1.15 & 0.09 \\
\hline
\end{tabular}




\begin{tabular}{|c|c|c|c|}
\hline $\mathbf{7}$ & 1.48 & 1.71 & 0.16 \\
\hline $\mathbf{8}$ & 1.65 & 2.29 & 0.39 \\
\hline $\mathbf{9}$ & 1.45 & 1.38 & 0.75 \\
\hline $\mathbf{1 0}$ & 1.06 & 1.66 & 0.36 \\
\hline $\mathbf{1 1}$ & 2.86 & 1.34 & 2.07 \\
\hline $\mathbf{1 2}$ & 1.40 & 2.05 & 0.26 \\
\hline $\mathbf{1 3}$ & 1.98 & 1.45 & 1.009 \\
\hline $\mathbf{1 4}$ & 2.57 & 1.61 & 0.47 \\
\hline
\end{tabular}

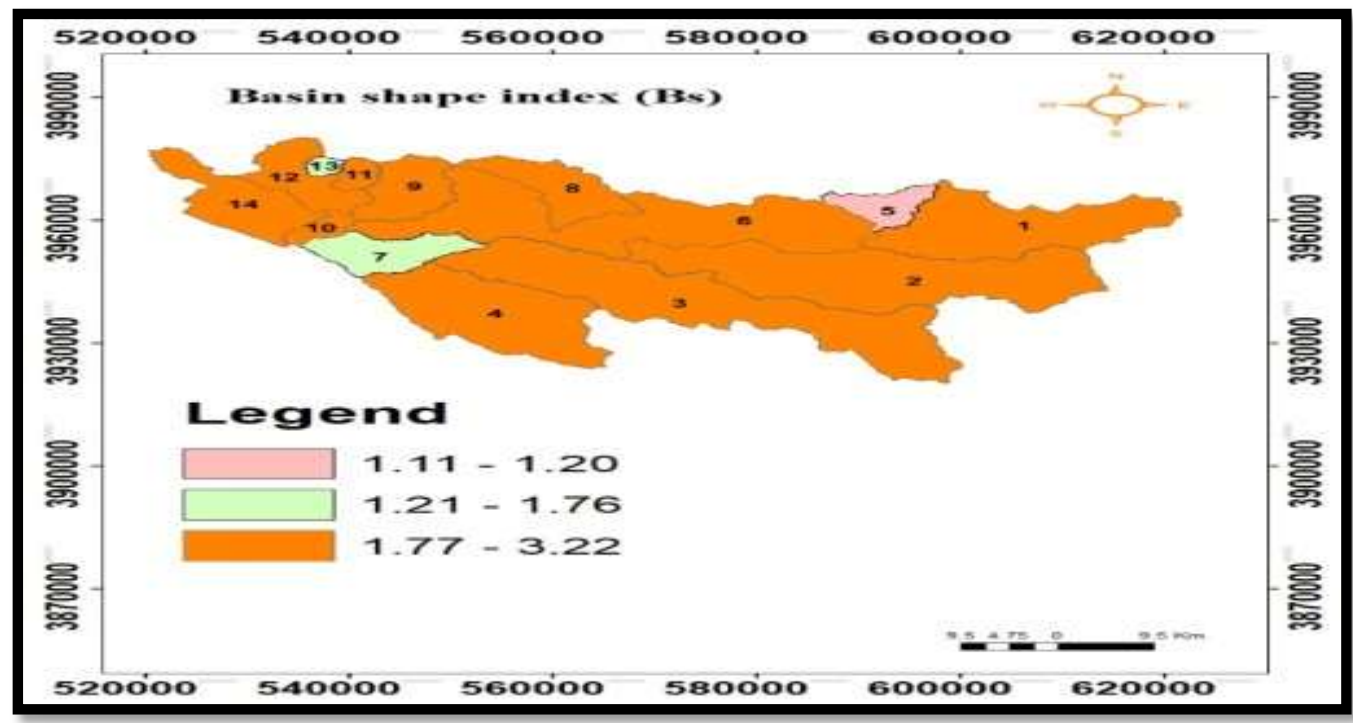

Figure 6-Distribution of (Bs) throughout the study area

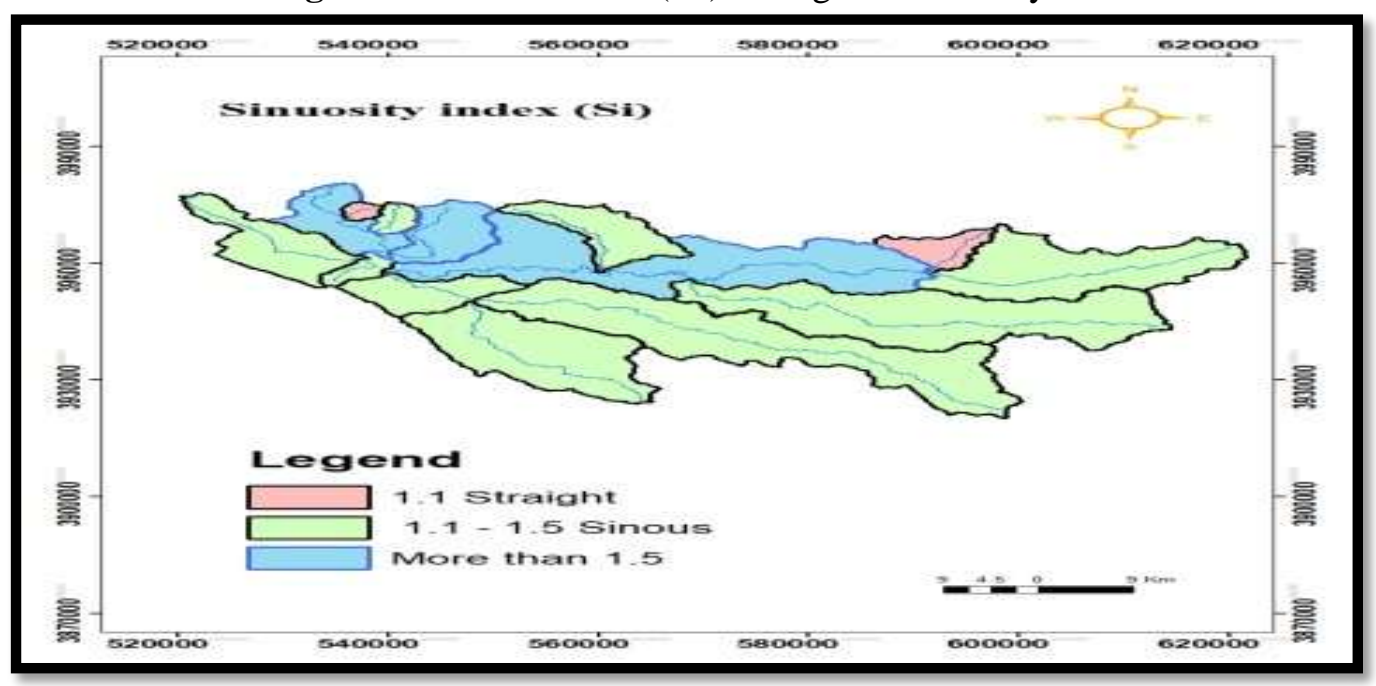

\section{Discussion}

Figure 7-Distribution of (Si) throughout the study area

The geomorphic index is an extensive means to analyze the influence of active tectonics. GIS and remote sensing packages serve over large areas as a reconnaissance tool to identify geomorphic anomalies that are probably connected to active tectonics [36]. Based upon the shape related indices, e.g. (Rf), (Rc), (Re), (Ls), and (Cc), the events were found to be similar for most sub-basins, which also had an elongated nature [31]. The circularly formed basins are connected with the tectonically undisturbed environment, while the elongated basins are connected with tectonically active regions. It is worth mentioning that the results of some of these indices can be caused by the irregularities in the designs of the sub-basins. The lower part of the chief branch basin, primarily in the high folded zone, can be found in many structures affecting the drainage system. The difference between the Zagros Suture Zone and the High Folded Zone is very important during the examination of the $(\mathrm{R})$ indicator, which, in turn, can be related to higher incision rates and erosion. Regarding the results of the 
geomorphic indices, the most maximum readings were found when using mixed parameters (Mountain front sinuosity and Valley floor width to valley height ratio) to provide semi-quantitative data of related rate of tectonic activity of mountain fronts. These coupled indices provide an assignation to different tectonic activity classes [29, 30]. A sample of different mountain fronts was analyzed in 14 sub-basins of the Sargalu area. Mountain front examination demonstrated that the lowest result was 1.15 in basin no. 3 and the highest result was 2.29 in basin no.8. Therefore, on the basis of the obtained results, all the mountain fronts in the 14 sub-basins of the Sargalu area fall within the „tectonically active fronte class 1 .

Table 8-Sub-basins location according to the Tectonic Zones

\begin{tabular}{|c|c|c|c|}
\hline \multicolumn{3}{|c|}{ Tectonic Zones } & \\
\hline Shalair Zone & Zagros Suture Zone & Imbricate Zone & High Folded Zone \\
\hline Sub-basins (1,2,5\& 6) & Sub-basins (4 and 9) & & $\mathbf{( 4 , 7 , 1 0 ~ \& 1 4 )}$ \\
\hline \multicolumn{2}{|c|}{ Sub-basins (3,6,8,9,11\&12) } & \\
\hline \multicolumn{2}{|c|}{ Sub-basins (3,6 \&12) } & \\
\hline
\end{tabular}

Drainage basin asymmetry values of (Af) for the 14 sub-basins range between 51 (sub-basin 8) and 71 (sub-basin 5). This simply indicates strong asymmetry. The results reveal the difference in spatial tectonic tilting at the unity plane because of the inequilibrium between the uplift and incision. Ideally, a tectonically constant area should show the value of 50, suggesting no tilting and incision. Drainage asymmetry higher or lower than 50 suggests tilting of the basin. This implies that values higher than 50 indicate that the main river channel is moving towards the left side of the basin downstream, while values lower than 50 indicate that the main river channel is shifting towards the right side of the basin downstream. That balance of uplift and tectonic activity ensures a high local diversify inside the region. Amongst geomorphic systems, drainage systems are highly receptive to active deformation, particularly in the folded and thrust areas. Distinguishes Drainage basin asymmetry that the sub-basins in the touching vicinity of thrust sand faults, should almost more chief values while sub-basins converge with the chief river channel and rising distance of the chief structures suggest approximately symmetric drainage system (Figure-7), In relation to the (T) index, the values are highly correlated with the Af values, which describes the high rates of asymmetry within the area. the idea For estimating the comparative active tectonics, the positive difference is what is essential, and values of Af-50 range from about 1 to 31 . In this study, we displayed the information on geomorphic indices other subjects that must be used to help the landscape in names of possible tectonic activity. Within common, the signs along with a special mountain front or region are examined and a judgment made concerning related tectonic activity [20, 29, 37, 38].

\section{Conclusions}

1- The study area is found in a very distinct tectonic area of northeastern Iraq, which involves three tectonic zones (Zagros Suture Zone, shalair zone, High Folded Zone and Imbricate Zone).

2- Different geomorphic indices must be examined in the Sargalu area to explain tectonic actions by using satellite remotely sensed datasets.

3- The study area contains 14 sub-basins; the sub-basin (3) has the highest altitude (550.659104 Km2) and the sub-basin (13) has the lowest $\left(13.880404 \mathrm{Km}^{2}\right)$.

4- Different morphometric indices showed consistent results that indicate that most sub-basins have an elongated nature.

5- In the 14 sub-basins of the study area, transverse topographic symmetry (T) analysis was performed. The parameters of Dd and Da were measured in various points within the mainstream of the entire basin. Within all sub-basin, chief aqueduct results explain that no-follow the basin this midline of, that flows both left or right show of the main channel. We measured this $\mathrm{T}$ about diverse points inside all basins count on at that length from the after calculation the basin and from the $\mathrm{T}$ in any areas, we studied the medium the basin rate of. Area In that study, geomorphic characteristics have a large influence on the movement from the canal from the middle. Underlying lithology, changed slope, and presence of various kinds of land cover and irrigation channels affected the tectonic structures. The analysis of $\mathrm{T}$ index in Sargalu area revealed that a tectonic incline has started within the North-West direction.

6- Channel sinuosity ( $\mathrm{Si}$ ) for the full SA to measure the importance from sinuosity during explaining the role of neotectonic activity that shifts the large distance channels are in a direction. It further 
produces evidence of the interplays of various patterns and processes that are effective inside the basin. Results of within 14 sub-basins range between 1.06 and the channel sinuosity 1.91. In common large sinuosity in the SA found values more than 1.4 (basin no. 6, 9, 10 and 12) are showing powerful sinuosity that communicates to the within that shape of tectonic structures predominating tectonic activity.

7- The main river basin's lower part, especially in the high folded zone, can be found in many structures affecting the drainage system. The difference between the Zagros Suture Zone and High Folded Zone was very distinguished during the analysis of the $(\mathrm{R})$ indicator, which, in turn, can be related to higher incision rates and erosion. Regarding the geomorphic indices results, to classify tectonic activity categories and provide data for the degree of activity of the mountain fronts, most of the researches applied a combination of two indicators. The lowest value of mountain fronts was 1.12 (SB7) and the highest result was 2.10 (SB6). Thus, the area may be classified as being of class 1 ,tectonically active front ${ }^{e e}$.

\section{ACKNOWLEDGMENT}

Shows the author his great thanks to the Iraq Geological Survey (GEOSURV), for their valuable help and assistance in GIS applications and for providing the Maps for the study area

\section{References}

1. Mark D.M. 1975. Geomorphic parameters: a review and evaluation. Geographiska annaler: series A. Phys. Geogr. 57(3/4): 165-177.

2. Thomas M.F. 2006. Lessons from the tropics for global geomorphology. Singap. J.Trop. Geogr. 27(2): 111-127.

3. Migon P. 2009. Are any granite landscapes distinctive of the humid tropics? Reconsidering multiconvex topographies. Singap. J. Trop. Geogr. 30327-342?

4. Panizza M. 2009. The geomorphodiversity of the dolomites (Italy): a key of geoheritage assessment. Geoheritage, 1(1): 33-42.

5. Walsh R.P.D., Blake, W.H., Slaymaker, O., Spencer, T. 2009. Tropical rainforests. In: Embleton Haman,C.(Ed.), Geomorphology and Global Environmental Change .Cambridge University Press, Cambridge, UK, pp. 214-243.

6. MacMillan R.A. and Shary, P.A. 2008. Chapter 9 landforms and landform elements in geomorphometry. Dev. Soil Sci. 33: 227-254.

7. Dragut L. and Eisank, C. 2012. Automated object-based classification of topography from SRTM data. Geomorphology, 141-142, 21-33.

8. Slaymaker O., Spencer, T. and Embleton-Haman, C. 2009. Geomorphology and Global Environment Change. Cambridge University Press, Cambridge, UK (468 pp).

9. Sabatier D. 2006. Evaluation Multi-Échelles de la Diversité Spécifique, Structurale ET Fonctionnelle des Arbres en Forêt Guyanaise: Prise en Compte du Substrat Géologique, des Sols ET de la Dynamique Sylvigénétique. Eosystèmes Tropicaux, Actes du 2ème Colloque de Restitution du Programme de Recherche. Ecofor Ministère de L'écologie ET du Développement Durable, Paris, France, pp. 125-133.

10. Guitet S., Pélissier, R., Brunaux, O., Jaouen, G., Sabatier, D. 2015b.Geomorphologicallandscape features explain floristic patterns in French Guiana rainforest. Biodivers. Conserv. 24(5): 12151237.

11. Hammond D.S. 2005. Tropical Forests of theGuiana Shield: Ancient Forests in a Modern World. CABI Publishing, Wallingford, UK (528 pp).

12. Keller E.A. 1986. Investigation of active tectonics: use of surficial Earth processes. In: Wallace, R.E.

13. Duvall A., Kirby, E. and Burbank, D. 2004. Tectonic and lithologic controls on bedrock channel profiles and processes in coastal California. Journal of Geophysical Research, 109: 1 -18. Doi: 10.1029/2003JF000086.

14. Wells' S. G. et al. 1988. 'Regional variations in tectonic geomorphology along a segmented convergent plate boundary pacific coast of Costa Rica', Geomorphology. 1(3): 239-265.

15. Burbank D.W. and Anderson, R.S. 2001. Tectonic Geomorphology. Blackwell Scientific, Oxford. $270 \mathrm{pp}$.

16. Keller EA. And Pinter N. 1996. Active tectonics: earthquakes uplift and landscapes. 2nd. Prentice- 
Hall, New Jersey, p. 338.

17. Bull, W.B. and McFadden, L.D. 1977. Tectonic Geomorphology North and South of the Garlock Fault, California. In: Doehring, D.O., Ed., Geomorphology in Arid Regions. Proceedings of the Eighth Annual Geomorphology Symposium, State University of New York, Binghamton, 115138.

18. Buday T. and Jassim, S. Z. 1984. Geological Map of Iraq, 1:1000000 Scale Series, Sheet No. 1,Tectonic Map, iraq, GEOSURV.

19. Fouad S.F. 2010. Tectonic Map of Iraq, scale 1:1,000,000, third ed. GEOSURV, Baghdad, Iraq.

20. Al-Kadhimi, J.A., Sissakian, V.K., Fattah, A.S. and Deikran, D.B. 1996. Tectonic Map of Iraq, scale 1: 1000 000, 2nd edit. GEOSURV, Baghdad, Iraq.

21. Jassim S. Z. and Goff, J. C. 2006. Geology of Iraq, Printing, Mosul, Iraq. doi: 10.1007/s13398014-0173-7.2.

22. Fouad S. F. A. 2015. 'Tectonic Map of Iraq, Scale 1: 1000000 ', Iraqi Bulletin of Geology and Mining, 11(1): 1-7.

23. Sissakian, V.K. 1998. the Geology of Erbil and Mahabad Quadrangles, Sheets No. NI - $38-14$ and NJ - 38-15 (GM 5 and 6), scale 1: 250000 GEOSURV, Baghdad Iraq.

24. Nookaratnam, K., Srivastava, Y. K., Venkateswarao, V., Amminedu, E. and Murthy, K.S.R. 2005. Check dam positioning by prioritization of micro-watersheds using SYI model and morphometric analysis - Remote sensing and GIS perspective, Journal of the Indian Society of Remote Sensing, 33(1): 25-28.

25. Strahler A. N. 1964. 'Part II. Quantitative geomorphology of drainage basins and channel networks', Handbook of Applied Hydrology: McGraw-Hill, New York, pp. 4-39.

26. Horton, R.E. 1945. Erosional development of streams and their drainage basins: hydrophysical approach to quantitative morphology. Bulletin of the Geological Society of America, 56: 275-3 70.

27. Thakkar, A. K. and Dhiman S. D. 2007. Morphometric analysis and prioritization on miniwatersheds in Mohr watershed, Gujrat using remote sensing and GIS techniques, Journal of Indian Society of Remote Sensing, 35(4): 313-321.

28. Abdul Jab'bar, M.F. 2012. Effect of Neotectonics Activity on Selected Structures in North and Northeastern part of Iraq. Unpub. M.Sc. Thesis, University of Baghdad, 113pp.

29. Wobus, C., K. X. Whipple, E. Kirby, N. Snyder, J. Johnson, K. Spyropolou, B. Crosby, and D. Sheehan 2006. Tectonics from topography:Procedures, promise, and pitfalls, Geol. Soc. Am. Spec. Pap., 398: 55-74.

30. Silva P.G., Goy, J.L., Zazo, C., Bardajm, T. 2003. Fault generated mountain fronts in Southeast Spain: geomorphologic assessment of tectonic and earthquake activity. Gemorphology, 250: 203226.

31. Bull, W. B. 2007. Tectonic geomorphology of mountains: A new approach to paleoseismology. Malden: Wiley-Blackwell. [DOI: 10.1002/9780470692318]

32. Rockwell T.K., Keller, E.A., Johnson, D.L. 1985. Tectonic geomorphology of alluvial fans and mountain fronts near Ventura, California. In: Morisawa, M. (Ed.), Tectonic Geomorphology. Proceedings of the 15th Annual Geomorphology Symposium. Allen and Unwin Publishers, Boston, MA, pp. 183-207.

33. Bull W.B. 2009. Tectonically Active Landscapes. Whilley, Blackwell, 326pp.

34. Jamieson, S. S. R., Sinclair, H. D., Kirstein, L. A. and Purves, R. S. 2004. Tectonic forcing of longitudinal valleys in the Himalaya: morphological analysis of the Ladakh Batholith, North India. Geomorphology, 58(1-4): 49-65. https://doi.org/10.1016/S0169-555X (03)00185-5.

35. Al-Kubaisi M.Sh. 2000. Morphotectonics of Tigris River and its tributaries in the folded zone of Iraq. Unpub. Ph.D. Thesis, University of Baghdad, 164p, (in Arabic).

36. Abdul Jab'bar, M.F. 2012. Effect of Neotectonics Activity on Selected Structures in North and Northeastern part of Iraq. Unpub. M.Sc. Thesis, University of Baghdad, 113pp.

37. El Hamdouni, R., Irigaray, C., Fernández, T., Chacón, J., Keller, E.A. 2008. Assessment of relative active tectonics, southwest border of the Sierra Nevada (southern Spain).Geomorphology 96: $150-173$.

38. Azor, A., Keller, E.A. and Yeats, R.S. 2002. Geomorphic Indicators of Active Fold Growth: South Mountain-Oak Ridge Ventura Basin, Southern California. Geological Society of America Bulletin, 114: $745-753$. 